University of Nebraska - Lincoln

DigitalCommons@University of Nebraska - Lincoln

Fragmentation Index of Raw Muscle as a Tenderness Predictor of Steaks from US Good and US Standard Steer and Bullock Carcasses

Chris R. Calkins

University of Nebraska-Lincoln, ccalkins1@unl.edu

G. W. Davis

University of Tennessee, Knoxville

Follow this and additional works at: https://digitalcommons.unl.edu/animalscifacpub

Part of the Animal Sciences Commons

Calkins, Chris R. and Davis, G. W., "Fragmentation Index of Raw Muscle as a Tenderness Predictor of Steaks from US Good and US Standard Steer and Bullock Carcasses" (1980). Faculty Papers and Publications in Animal Science. 570.

https://digitalcommons.unl.edu/animalscifacpub/570

This Article is brought to you for free and open access by the Animal Science Department at DigitalCommons@University of Nebraska - Lincoln. It has been accepted for inclusion in Faculty Papers and Publications in Animal Science by an authorized administrator of DigitalCommons@University of Nebraska - Lincoln. 


\title{
FRAGMENTATION INDEX OF RAW MUSCLE AS A TENDERNESS PREDICTOR OF STEAKS FROM US GOOD AND US STANDARD STEER AND BULLOCK CARCASSES
}

\author{
C. R. Calkins ${ }^{1}$ and G. W. Davis ${ }^{2}$ \\ Tennessee Agricultural Experiment Station, University of Tennessee, \\ Knoxville 37916
}

\begin{abstract}
Summary
Thirty steer (10 US Good, 20 US Standard) and 10 bullock carcasses (one US Good, nine US Standard) were selected from two commercial meat packing firms and aged for 10 to 14 days in a $2 \mathrm{C}$ cooler. Each carcass was assigned scores for the various USDA quality and yield grade factors during a 48 - to 120 -hr postmortem selection period. Steaks containing the longissimus muscle were obtained from the anterior end of the short loin and cooked to $70 \mathrm{C}$. They were then measured for tenderness with the Warner-Bratzler shear and evaluated by a trained eight-member sensory panel. Fragmentation index (FI) was determined on fresh and frozen raw longissimus muscle at each of three posthomogenization residue fraction drying periods $(10 \mathrm{~min}, 40 \mathrm{~min}$ and $24 \mathrm{hr}$ ). Sarcomere length also was determined. Simple correlation coefficients relating FI (10 min, 40 min and $22 \mathrm{hr}$ ) to tenderness rating for bullocks were: (1) $-.74,-.75$ and -.72 , respectively, for fresh muscle and (2) $-.70,-.66$ and -.69 , respectively, for frozen muscle Fl. Simultaneous consideration of carcass physical traits, sarcomere length and eight FI values accounted for 78.7 and $72.6 \%$ of the observed variation in shear force value and tenderness rating of steaks from the 30 US Good and US Standard steer carcasses. FI determined from fresh longissimus muscle accounted for 48.4 and $44.5 \%$ more of the variation in cooked meat tenderness than did carcass physical traits and sarcomere length. The best prediction equations for fragmentation of either fresh or
\end{abstract}

\footnotetext{
${ }^{1}$ Formerly with the Univ. of Tennessee; presently affiliated with Meats and Muscle Biol. Sec. Dept. of Anim. Sci., Texas A\&M Univ., College Station.

${ }^{2}$ Dept. of Food Technol, and Sci.
}

frozen raw muscle accounted for over $53 \%$ of the observed variation in cooked meat shear force values; this degree of precision can be achieved in approximately 15 min of laboratory time. These data indicate that FI of raw muscle can be used for stratification of low grading bullock and steer carcasses according to tenderness level of cooked loin steaks.

(Key Words: Fragmentation, Tenderness, Beef, US Good, US Standard, Bullock.)

\section{Introduction}

Recently, much effort has been extended to clarify the relationship between raw muscle fragmentation and cooked meat tenderness (Moller et al., 1973; Berry et al., 1974; Reagan et al., 1975; Olson and Parrish, 1977; Culler et al., 1978; Davis et al., 1979; Calkins et al., 1980). A variety of procedures and quantitation methods exist for fragmenting raw muscle: Davis et al. (1980) expressed a fragmentation index (FI) based on the residue weight of fragments more than $250 \mu \mathrm{m}$ in size; Berry et al. (1974) reported the percentage of short fiber fragments observed microscopically, and Moller et al. (1973) and Olson et al. (1976) measured absorbance of a myofibril suspension.

Commerical application of fragmentation would require the use of a rapid simple and accurate procedure. Calkins et al. (1980) reported success in identifying tender carcasses within the US Commerical or US Utility grades with the FI procedure developed by Davis et al. (1980). The researchers concluded that fragmentation of frozen, raw longissimus muscle accounted for $56.6 \%$ of the observed variation in shear force value of cooked loin steaks.

Since there is considerable variation in the palatability of bullock carcasses (USDA, 1972) and since the US Standard grade has been 
broadened (USDA, 1976), an economic advantage might be realized if certain tender carcasses within these classifications could be objectively identified. The objective of the present study was to determine the relationship between fragmentation of raw muscle (fresh and frozen) and cooked meat tenderness of steaks from bullock and low quality steer carcasses.

\section{Experimental Procedure}

Thirty steer (10 US Good, 20 US Standard) and 10 bullock carcasses (nine US Good, one US Standard) were evaluated for grade factors at 48 - to $120-\mathrm{hr}$ postmortem and transported to the University of Tennessee meat laboratory. After an aging period of 10 to 14 days in a $2 \mathrm{C}$ cooler, three steaks were removed from the anterior end of the short loin. Steak A $(.65 \mathrm{~cm}$ thick) was obtained for fragmentation and sarcomere length determination. Palatability and shear force value were determined for steaks B and $\mathrm{C}(3.2 \mathrm{~cm}$ thick$)$.

FI for fresh and frozen raw muscle was determined by the procedure of Davis et al., (1980). Dorsal blade depth was maintained at 1 $\mathrm{mm}$ (Calkins and Davis, 1978) below the surface of the solution, and weights of residue fractions were taken at $10 \mathrm{~min}, 40 \mathrm{~min}(22 \mathrm{C}$

TABLE 1. MEANS AND COEFFICIENTS OF VARIATION FOR PHYSICAL TRAITS, PALATABILITY ATTRIBUTES, SHEAR FORCE VALUE AND FRAGMENTATION MEASURES FOR BULLOCK AND STEER CARCASSES

\begin{tabular}{|c|c|c|c|c|}
\hline \multirow[b]{2}{*}{ Trait } & \multicolumn{2}{|c|}{ Bullocks ${ }^{a}$} & \multicolumn{2}{|c|}{ Steers ${ }^{\mathbf{a}}$} \\
\hline & Mean & $\mathrm{CV}^{\mathrm{b}}$ & Mean & $\mathrm{CV}^{\mathrm{b}}$ \\
\hline \multicolumn{5}{|l|}{ Physical traits } \\
\hline Marblingc & 21.2 & 33.78 & 27.0 & 19.07 \\
\hline Lean colord & 5.2 & 34.88 & 6.1 & 13.64 \\
\hline Lean firmness & 3.4 & 60.75 & 5.3 & 25.88 \\
\hline Lean texture $\bar{d}$ & 5.9 & 44.09 & 7.1 & 16.55 \\
\hline Fat thickness, mm & 1.4 & 131.74 & 6.4 & 50.25 \\
\hline Carcass weight, $\mathrm{kg}$ & 227.6 & 16.18 & 205.0 & 13.13 \\
\hline Sarcomere length, $\mu \mathrm{m}$ & 1.76 & 8.93 & 1.81 & 7.33 \\
\hline \multicolumn{5}{|l|}{ Palatability attributes ${ }^{e}$} \\
\hline Tenderness rating & 4.5 & 27.70 & 5.6 & 22.17 \\
\hline Juiciness rating & 4.9 & 11.62 & 4.8 & 11.21 \\
\hline Connective tissue rating & 6.8 & 12.01 & 7.6 & 4.30 \\
\hline Flavor desirability rating & 4.5 & 27.42 & 5.8 & 11.10 \\
\hline Overall satisfaction rating & 4.4 & 26.51 & 5.3 & 17.41 \\
\hline Shear force value, $\mathrm{kg}$ & 5.39 & 40.71 & 3.97 & 42.36 \\
\hline \multicolumn{5}{|l|}{ Fragmentation index $f$} \\
\hline Fresh, $10 \mathrm{~min}$ & 235.4 & 55.13 & 147.3 & 65.04 \\
\hline Fresh, $40 \mathrm{~min}$ & 205.1 & 55.43 & 126.8 & 67.27 \\
\hline Fresh, 22 hrs & 48.6 & 53.47 & 32.8 & 64.29 \\
\hline Fresh, filtrate volume, $\mathrm{ml}$ & 54.3 & 5.49 & 55.3 & 4.20 \\
\hline Frozen, $10 \mathrm{~min}$ & 346.3 & 50.81 & 271.3 & 48.65 \\
\hline Frozen, $40 \mathrm{~min}$ & 301.7 & 49.12 & 235.6 & 49.14 \\
\hline Frozen, 22 hr & 75.1 & 51.98 & 64.1 & 52.62 \\
\hline Frozen, filtrate volume, $\mathrm{mi}$ & 52.0 & 5.31 & 53.3 & 4.54 \\
\hline
\end{tabular}

${ }^{\text {a } B u l l o c k s: ~ o n e ~ U S ~ G o o d, ~ n i n e ~ U S ~ S t a n d a r d ; ~ s t e e r s: ~} 10$ US Good, 20 US Standard.

${ }^{b} \mathrm{CV}=$ coefficient of variation.

$\mathrm{c}_{\text {Mean based on } 100-\text { unit scale }(70=\text { Slightly abundant }}{ }^{\circ \circ}, 30=$ Slight $\left.^{\circ \circ}\right)$.

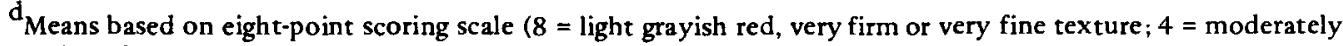
dark red, slightly soft or slightly coarse).

${ }^{e}$ Means based on eight-point rating scale $(9=$ extremely tender, extremely juicy, extremely desirable flavor, no connective tissue or extremely desirable overall; 1 = extremely tough, extremely dry, extremely undesirable flavor, abundant amount of connective tissue or extremely undesirable overall).

$\mathrm{f}_{\text {Fragmentation index }}=100 \times$ weight (grams) after air drying at $22 \mathrm{C}(10 \mathrm{~min}$ and $40 \mathrm{~min})$ and oven drying at $35 \mathrm{C}(22 \mathrm{hr})$. 
air dry) and $22 \mathrm{hr}$ (35 C oven dry) for both fresh and frozen raw longissimus muscle. Filtrate volume was also recorded.

Samples for sarcomere length were blended in an Osterizer Cycle-Blend for 90 seconds. The suspension medium was $4 \%$ formalin $(25 \mathrm{ml})$. A light microscope $(x 1,500)$ and filar micrometer were used to measure 10 sarcomeres on each of 12 myofibrils.

Sensory evaluation (steak B) and shear force value (steak $C$ ) were obtained on steaks cooked to an internal temperature of $70 \mathrm{C}$ on individual, preheated broiling units. Final internal temperature was monitored by thermocouples. Steaks B and C, previously frozen at $-31 \mathrm{C}$ and stored at $-18 \mathrm{C}$, were thawed for $24 \mathrm{hr}$ in a 5 to $7 \mathrm{C}$ cooler before being cooked. A trained, eight-member sensory panel evaluated tenderness, juiciness, connective tissue amount, flavor desirability and overall satisfaction for each sample, using eight-point rating scales $(8=$ extremely tender, extremely juicy, no connective tissue, extremely desirable flavor or extremely desirable overall; 1 = extremely tough, extremely dry, abundant connective tissue, extremely undesirable flavor or extremely undesirable overall). Steak $\mathrm{C}$ was cooled to 25 $C$, and four $1.3-\mathrm{cm}$ cores were removed and sheared in duplicate on a Warner-Bratzler shear.

Data were analyzed according to guidelines outlined by Steel and Torrie (1960).

\section{Results and Discussion}

Mean values for various physical, palatability, shear and fragmentation measures on the steer and bullock carcass samples are presented in table 1. The 10 US Good and 20 US Standard steer carcasses were pooled into one group of 30 , because an analysis of variance for USDA quality grade with sensory tenderness and shear force value as dependent variables resulted in nonsignificant $F$ values of .00 and .54 . Among steaks from the low grading steer carcasses $(n=$ 30 ), increased tenderness was associated with decreased FI values for fresh and frozen raw muscle at all drying times (table 1). Comparison of data for steaks from steer and bullock carcasses shows the samples from steer carcasses (1) were rated 1.1 tenderness units higher by the sensory panel, (2) were $1.42 \mathrm{~kg}$ lower in shear force value and (3) had an FI 11.0 to 88.1

TABLE 2.SIMPLE CORRELATION COEFFICIENTS RELATING FRAGMENTATION MEASURES TO PHYSICAL TRAITS, PALATABILITY ATTRIBUTES AND SHEAR FORCE VALUE FOR BULLOCK CARCASSES ${ }^{a}$

\begin{tabular}{|c|c|c|c|c|c|c|c|c|}
\hline \multirow[b]{2}{*}{ Trait } & \multicolumn{4}{|c|}{ Fragmentation of fresh muscleb } & \multicolumn{4}{|c|}{ Fragmentation of frozen muscleb } \\
\hline & $\begin{array}{l}10 \\
\min \end{array}$ & $\begin{array}{l}40 \\
\min \end{array}$ & $\begin{array}{l}22 \\
\mathrm{hr}\end{array}$ & $\begin{array}{l}\text { Filtrate } \\
\text { volume }\end{array}$ & $\begin{array}{l}10 \\
\min \end{array}$ & $\begin{array}{l}40 \\
\mathrm{~min}\end{array}$ & $\begin{array}{l}22 \\
\mathrm{hr}\end{array}$ & $\begin{array}{l}\text { Filtrate } \\
\text { volume }\end{array}$ \\
\hline \multicolumn{9}{|l|}{ Physical traits } \\
\hline Marbling & .16 & .15 & .20 & -.26 & -.12 & -.11 & -.09 & .20 \\
\hline Lean color & -.65 & -.67 & -.59 & .72 & -.55 & -.51 & .37 & $-.68^{*}$ \\
\hline Lean firmness & .21 & .20 & .27 & .22 & -.10 & -.07 & -.04 & .17 \\
\hline Lean texture & $-.77^{* *}$ & $-.78 * *$ & $-.75^{*}$ & $.61^{*}$ & -.51 & -.45 & -.41 & $.68^{*}$ \\
\hline Fat thickness & -.23 & -.24 & -.19 & .24 & -.11 & -.06 & .02 & .31 \\
\hline Carcass Weight & .47 & .45 & .51 & -.50 & .54 & .55 & .61 & -.38 \\
\hline Sarcomere length & -.42 & -.44 & -.37 & .33 & -.37 & -.30 & -.23 & .59 \\
\hline \multirow{3}{*}{$\begin{array}{l}\text { Palatability attribute } \\
\text { Tenderness rating } \\
\text { Overall satisfaction } \\
\text { rating }\end{array}$} & & & & & & & & \\
\hline & $-.74^{*}$ & $-.75^{*}$ & $-.72 *$ & .52 & $-.70^{*}$ & $-.66^{*}$ & $-.69^{*}$ & $.73^{*}$ \\
\hline & $-.73^{*}$ & $-.74^{*}$ & $-.72^{*}$ & .51 & $-.65^{*}$ & -.61 & -.63 & $.73^{*}$ \\
\hline Shear force value & .38 & .39 & .36 & -.18 & .53 & .50 & .52 & -.56 \\
\hline
\end{tabular}

\footnotetext{
${ }^{\mathrm{a}} \mathrm{N}=10$ (one US Good, nine US Standard).

$\mathrm{b}_{\text {Fragmentation index }}=100 \times$ weight (grams) after air drying at $22 \mathrm{C}(10 \mathrm{~min}$ and $40 \mathrm{~min}$ ) and oven drying at $35 \mathrm{C}(22 \mathrm{hr})$

$* \mathrm{P}<.05$.

$* * \mathrm{P}<.01$
} 
units higher. These data indicate that the FI can segment slightly tender (steer) from slightly tough (bullock) cooked steaks with the use of fresh or frozen raw muscle.

FI of raw muscle from bullock carcasses was significantly related to tenderness rating in seven of eight comparisons (table 2). Subjective lean color and lean firmness scores for bullock carcasses (one US Good, nine US Standard) were significantly related $(\mathrm{P}<.05)$ to two to five measures of fragmentation (table 2). These data indicate that a bullock carcass with a youthfulcolored, fine-textered lean will most likely be rated tender and possess a lower FI than a bullock carcass with dark, coarse-textured lean. The significant association between $\mathrm{Fl}$ and lean texture (table 2) is in agreement with values reported by Calkins et al. (1980) for US Commercial and US Utility beef.

Simple correlation coefficients relating fragmentation measures to physical traits and sensory ratings of the US Good and US Standard steer carcasses are presented in table 3. All fragmentation values (fresh and frozen muscle) were significantly correlated with the sensory tenderness rating and shear force value (table 3 ). The correlation coefficients in tables 2 and 3 for lower grading, A maturity carcasses are in agreement with the coefficients between FI and tenderness reported by Calkins et al. (1980) for US Commercial and US Utility beef and by Davis et al. (1980) for US Choice, US Good and US Commercial carcasses. The coefficients also agree with values between MFI and tenderness reported by Olson and Parrish (1977). Culler et al. (1978) and Parrish et al. (1979).

Twelve physical and histological variables accounted for apporximately $75 \%$ of the observed variation in shear force value or tenderness rating of steaks from the 30 US Good and US Standard steer carcasses (table 4). Physical traits (marbling degree, lean color, lean texture, carcass weight and fat thickness) and sarcomere length were included first in the model. Results of the analysis (table 4) indicate that physical traits and sarcomere length accounted for approximately 27.5 and $24.3 \%$ of the variation in shear force value and tenderness rating. Because of the time required to obtain an FI from a residue fraction oven dried for $22 \mathrm{hr}$, the following fragmentation values were included next: $10 \mathrm{~min} \mathrm{FI,} 40 \mathrm{~min} \mathrm{FI,} \mathrm{and}$ filtrate volume (fresh and frozen raw muscle). The data (table 4) reveal that fresh muscle fragmentaion values explained 48.40 and

TABLE 3. SIMPLE CORRELATION COEFFICIENTS RELATING FRAGMENTATION MEASURES TO PHYSICAL TRAITS, PALATABILITY ATTRIBUTES AND SHEAR FORCE VALUE FOR US GOOD AND US STANDARD STEER CARCASSES $(n=30)$

\begin{tabular}{|c|c|c|c|c|c|c|c|c|}
\hline \multirow[b]{2}{*}{ Trait } & \multicolumn{4}{|c|}{ Fragmentation of fresh musclea } & \multicolumn{4}{|c|}{ Fragmentation of frozen musclea } \\
\hline & $\begin{array}{l}10 \\
\min \end{array}$ & $\begin{array}{l}40 \\
\min \end{array}$ & $\begin{array}{l}22 \\
\mathrm{hr}\end{array}$ & $\begin{array}{l}\text { Filtrate } \\
\text { volume }\end{array}$ & $\begin{array}{l}10 \\
\min \end{array}$ & $\begin{array}{l}40 \\
\min \end{array}$ & $\begin{array}{l}22 \\
\mathrm{hr}\end{array}$ & $\begin{array}{l}\text { Filtrate } \\
\text { volume }\end{array}$ \\
\hline \multicolumn{9}{|l|}{ Physical traits } \\
\hline Marbling & -.13 & -.15 & -.11 & .04 & -.19 & -.21 & -.08 & .33 \\
\hline Lean color & -.02 & -.04 & -.04 & .18 & .01 & .00 & -.03 & .05 \\
\hline Lean firmness & -.33 & -.34 & -.31 & $.42 *$ & -.26 & -.25 & -.21 & .35 \\
\hline Lean texture & $-.43^{*}$ & $-.45^{* *}$ & $-.43^{*}$ & $.53^{* *}$ & -.29 & -.30 & -.25 & $.49 * *$ \\
\hline Fat thickness & $-.48 * *$ & $-.49^{* *}$ & $-.47 * *$ & .36 & $-.54 * *$ & $-.51 * *$ & $-.48 * *$ & $.52^{* *}$ \\
\hline Sarcomere length & .10 & .10 & .10 & -.13 & .02 & .02 & .09 & .00 \\
\hline \multicolumn{9}{|l|}{ Palatability attributes } \\
\hline Tenderness rating & $-.71^{* *}$ & $-.71 * *$ & $-.70^{* *}$ & $.56^{* *}$ & $-.66^{* *}$ & $-.64^{* *}$ & $-.60^{* *}$ & $.65^{* * *}$ \\
\hline rating & $-.68 * *$ & $-.68 * *$ & $-.66 * *$ & $.51^{* *}$ & $-.63 * *$ & $-.62 * *$ & $-.56 * *$ & $.64 * *$ \\
\hline Shear force value & $.64^{* *}$ & $.64^{* *}$ & $.63^{* *}$ & $-.41^{*}$ & $.73^{* *}$ & $.72 * *$ & $.66^{* *}$ & $-.67 * *$ \\
\hline
\end{tabular}

\footnotetext{
${ }^{\mathrm{a}}$ Fragmentation index $=100 \times$ weight (grams) after air drying at $22 \mathrm{C}(10 \mathrm{~min}$ and $40 \mathrm{~min})$ and oven drying at $35 \mathrm{C}(22 \mathrm{hr})$.

* $\mathrm{P}<.05$.

$* * \mathrm{P}<.01$.
} 
TABLE 4. COEFFICIENTS OF DETERMINATION AND PARTIAL COEFFICIENTS OF

DETERMINATION FOR PREDICTION OF SHEAR FORCE VALUE AND

TENDERNESS RATING OF STEAKS FROM US GOOD AND US

STANDARD STEER CARCASSES BY CERTAIN PHYSICAL TRAITS AND FRAGMENTATION MEASURES

\begin{tabular}{|c|c|c|}
\hline Model & $\begin{array}{l}\text { Shear } \\
\text { force } \\
\text { value } \\
\mathrm{R}^{2} \times 100\end{array}$ & $\begin{array}{l}\text { Tenderness } \\
\text { rating } \\
R^{2} \times 100\end{array}$ \\
\hline $\begin{array}{l}\text { Physical traits } a \text {, fresh muscle fragmentation } b \text {, } \\
\text { frozen muscle fragmentation } b\end{array}$ & 78.70 & 72.60 \\
\hline Physical traits & 27.47 & 24.34 \\
\hline Fresh muscle fragmentation/physical traits $\mathrm{c}$ & 48.40 & 44.48 \\
\hline $\begin{array}{l}\text { Frozen muscle fragmentation/physical traits, } \\
\text { fresh muscle fragmentation } \mathrm{d}\end{array}$ & 2.83 & 3.78 \\
\hline
\end{tabular}
length.

${ }^{\mathbf{a}}$ Physical traits include marbling degree, lean color, lean texture, carcass weight, fat thickness and sarcomere

${ }^{\mathrm{b}}$ Fragmentaion measures include $10-\mathrm{min}$ index, 40-min index and filtrate volume for fresh and frozen longissimus muscle.

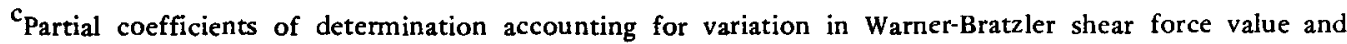
tenderness rating which was not previously explained by physical traits.

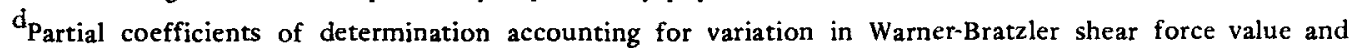
tenderness rating which was not previously explained by fresh muscle fragmentaion and physical traits.

$44.48 \%$ of the variation in WBS force value and tenderness rating above that variation accounted for by physical traits and sarcomere length.

Regression equations for predicting shear force value of steaks from US Good and US Standard carcasses are presented in table 5. These data were developed in an attempt to identify the percentage of the observed variability in tenderness that could be accounted for by use of one or two measures of fragmentation. The best single fragmentation measure for use of fresh and frozen raw muscle accounted for 41.56 and $53.09 \%$ of the observed variation in shear force value. An additional $16.45 \%$ (fresh muscle) and $.08 \%$ (frozen muscle) precision was attained when a second fragmentation variable was used to predict shear force value (table 5). With precision and laboratory time considered, the best prediction equations for fresh (10 min FI and filtrate volume) and frozen (10 min FI) raw muscle accounted for over $53 \%$ of the observed variation in cooked meat shear force values. This degree of precision can be achieved in approximately $15 \mathrm{~min}$ (including homogenization, filtration and fragment drying time periods). To facilitate the routine determination of $\mathrm{FI}$, it may be more desirable to use fresh rather than frozen raw muscle, especially since the 5 -min thawing time period can be eliminated and, as evidence in table 4 indicates, fragmentation of frozen muscle adds less than $4 \%$ precision to prediction of cooked meat tenderness. Conversely, in a study of US Commercial and US Utility carcasses, Calkins et al. (1980) has reported that

TABLE 5. REGRESSION EQUATIONS FOR PREDICTION OF SHEAR FORCE VALUE OF STEAKS FROM US GOOD AND US STANDARD STEER CARCASSES WITH USE OF CERTAIN FRAGMENTATION MEASURES

\begin{tabular}{llll}
\hline $\begin{array}{l}\text { State } \\
\text { of raw } \\
\text { muscle }\end{array}$ & Variables $^{\mathrm{a}}$ & $\mathrm{R}^{2} \times 100$ & $\mathrm{SEE}^{\mathrm{b}}$ \\
\hline Fresh & 1,3 & 58.01 & 2.49 \\
Fresh & 1 & 41.56 & 2.88 \\
Frozen & 1,2 & 53.17 & 2.62 \\
Frozen & 1 & 53.09 & 2.58 \\
\hline
\end{tabular}

${ }^{a}$ Variable code for fragmentation measures:

1 = FI after air drying of residue fraction at 22 $C$ for 10 minutes.

2 = FI after air drying of residue fraction at 22 C for 40 minutes.

$3=$ Filtrate volume.

${ }^{\mathrm{b}} \mathrm{SEE}=$ standard error of the estimate. 
FI determined from frozen longissimus muscle acc sunted for 18.6 to $23.8 \%$ more of the observed variation in cooked meat tenderness than did FI of fresh muscle.

On the basis of (1) the data presented herein for lower grading, A maturity steer and bullock carcasses; (2) results obtained by Calkins et al. (1980) for C maturity carcasses, and (3) data reported by Stiffler and Ray (1979) for short scrotum and steer carcasses, it appears that the FI procedure (Davis et al., 1980) may have potential for industrial application and (or) as a routine meat science research technique. The above uses are suggested since fragmentation can be performed in approximately $15 \mathrm{~min}$ on raw muscle representing a wide range of carcasses and account for over $53 \%$ of the observed variation in cooked meat tenderness.

Conclusions of our major findings in the present study were that: (1) FI of raw muscle for low grading bullock carcasses was significantly related to tenderness rating of cooked loin steaks. (2) Fragmentation values were superior to physical traits and sarcomere length in segmenting low grading steer carcasses according to tenderness rating or shear force value of cooked loin steaks. (3) Neither FI of raw muscle nor sensory tenderness and shear force value of cooked steaks were successful in segmenting US Good from US Standard steer carcasses. (4) The best prediction equations for fragmentation of either fresh or frozen raw muscle accounted for over $53 \%$ of the observed variation in cooked meat shear force values, a degree of precision which can be achieved in approximately $15 \mathrm{~min}$ of laboratory time.

\section{Literature Cited}

Berry, B. W., G. C. Smith and Z. L. Carpenter. 1974. Relationships of certain muscle, cartilage and bone traits to tenderness of the beef Longissimus. J. Food Sci. 39:819.

Calkins, C. R. and G. W. Davis. 1978. Refinement of a muscle fragmentation procedure for predicting cooked meat tenderness. Tennessee Farm and Home Sci. 108: 14.

Calkins, C. R., G. W. Davis and W. L. Sanders. 1980. Fragmentation index of raw muscle as a tenderness predictor of steaks from USDA Commercial and Utility carcasses. J. Food. Sci. 45:111.

Culler, R. D., F. C. Parrish, Jr., G. C. Smith and H. R. Cross. 1978. Relationship of myofibril fragmentation to certain chemical, physical and sensory characteristics of bovine longissimus muscle. J. Food Sci. 43:1177.

Davis, G. W., T. R. Dutson, G. C. Smith and Z. L. Carpenter. 1980. Fragmentation of bovine longissimus muscle as an index of cooked steak tenderness. J. Food Sci. 45:880.

Davis, G. W., G. C. Smith, Z. L. Carpenter, T. R. Dutson and H. R. Cross. 1979. Physical, chemical and histological factors associated with variability in tenderness among beef carcasses of the same USDA grade. J. Anim. Sci. 49:103.

Moller, A. J., T. Vestergaard and J. Wismer-Pedersen. 1973. Myofibril fragmentation in bovine longissimus dorsi as an index of tenderness. J. Food Sci. 38:824.

Olson, D. G. and F. C. Parrish, Jr. 1977. Relationship of myofibril fragmentation index to measures of beefsteak tenderness. J. Food Sci. 42:506.

Olson, D. G., F. C. Parrish Jr. and M. H. Stromer. 1976. Myofibril fragmentation and shear resistance of three bovine muscles during postmortem storage. J. Food Sci. 41:1036.

Parrish, F. C., Jr., C. J. Vendell and R. D. Culler. 1979. Effect of maturity and marbling on the myofibril fragmentation index of bovine longissimus muscle J. Food Sci. 44:1668.

Reagan, J. O., T. R. Dutson, Z. L. Carpenter and G. C. Smith. 1975. Muscle fragmentation indices for predicting cooked beef tenderness. J. Food Sci. 40: 1093 .

Steel, R, G. and J. H. Torrie. 1960. Principles and Procedures of Statistics. McGraw-Hill Book Co., New York.

Stiffler, D. M. and E. E. Ray. 1979. Associations between raw fragmentation and cooked shear force for electrically stimulated short scrotum and steer longissimus muscle. J. Anim. Sci. 49(Suppl. 1):232.

USDA. 1972. Proposed rule making: Carcass beef, slaughter cattle. USDA, C\&MS, Federal Register, March 17.

USDA. 1976. Official United States Standards for Grades of Carcass Beef. Agr. Marketing Service, USDA, Washington DC. 